\title{
The Effect of Round Table Cooperative Learning Model and Learning Motivation On Students' Critical Thinking Skills
}

\author{
Y Suryani $^{1}$, E Nurfadilah $^{2}$, I Setiawan ${ }^{3}$, C Suhartini $^{4}$ \\ Department of Economic Education, Faculty of Teacher Training and Education, Universitas Kuningan, \\ Indonesia \\ Email: yeyen.suryani@uniku.ac.id
}

\begin{abstract}
As reflected in students' scores in the preliminary study, students' critical thinking skills are proved to be in the low-level. Hence, this study aims to identify; 1) the differences on the level of critical thinking skills between students who were taught by using Round Table and lecture method; 2) the differences on the level of critical thinking skills between students who have high, moderate, and low learning motivation; and 3) the effect of the interaction between Round Table learning model and students' learning motivation on students' critical thinking skills. This quasi-experimental study applied a "two-factors between subject" design and involved 35 students of class X IPS 3 of SMA Negeri 1 Cilimus as control class and 35 students of X IPS 4 as experimental class. As results, it was found that: 1) there is a difference on the level of critical thinking skills between students who were taught by using Round Table and lecture method;2) there is a difference on the level of critical thinking skills between students who have high, moderate, and low learning motivation; and 3) there is no effect of the interaction between Round Table learning model and students' learning motivation on students' critical thinking skills.
\end{abstract}

Keywords: learning model; critical thinking skills; Cilimus

\section{Introduction}

21 st century education requires students to have innovative learning skills, information, media and technology skills as well as life skills in order to be able to work and survive. Besides, as life gets more complicated in this rapid development of science and technology era, students are forced to develop their critical thinking skills in order to prepare them in facing this increasingly advanced and competitive life. Critical thinking skill is a complex thinking process in analyzing and evaluating information obtained from experience, observation, and/or discussion with other people to draw a conclusion or to make a decision. It means that students who have critical thinking skills will be able to analyze any information obtained to make a decision based on further considerations.

However, in fact, critical thinking skill has not been optimally promoted in the learning process, especially in economic subject, as it can be seen from the lack of students' involvement. Here, the students can only passively listen to the teacher's explanation. This traditional teaching method emphasizes on lower-order thinking skills, including remembering/memorizing, understanding, and applying. 
Based on the results of preliminary observations, there are still a lot of students who do not possess critical thinking skills yet as it can be seen from the number of students who do not dare to express their ideas, have difficulty connecting what is learned to how that knowledge is used to solve everyday problems, have difficulty drawing a conclusion, have not been able to analyze arguments, and have no initiative to ask questions. The low-level of students' critical thinking skills is also proved by a preliminary study conducted by the researchers in class X IPS on economic subjects in which there are still many students who got score below the Minimum Completeness Criteria (KKM). The results of the preliminary study are summed up in Figure 1.

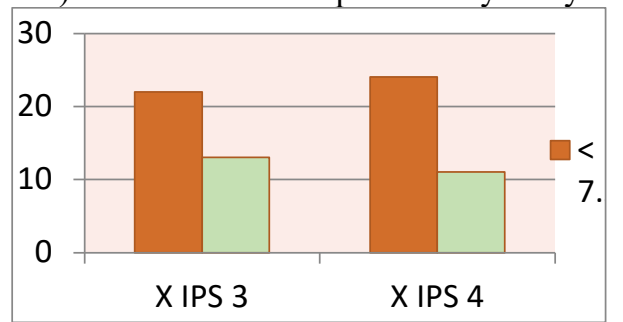

Fig1. Results of Preliminary Study On Critical Thinking Skills at SMAN 1 Cilimus

Figure 1 shows that there are still many students who got score below the minimum completeness criteria (KKM) which is set at 75 . Of the 70 students who were divided into 2 classes, 46 students (65.7\%) got score below the KKM and 24 students (34.3\%) got score above the KKM. This data reflects that students' critical thinking skills are still in the low-level. Hence, in an effort to improve students' critical thinking skills, teachers should be able to create an active and interactive learning atmosphere.

As stated by Susilo [1], an effort needed to improve the quality of education in schools is to improve the learning process. Basically, there are several factors affecting the low-level of students' critical thinking skills which are divided into internal and external factors. One of the external factors affecting the low-level of students' critical thinking skills is the learning model applied. Here, teachers need to carefully select a learning model as it will give a great impact on students' thinking skills. One of the learning models that can be applied to improve students' critical thinking skills is Round Table cooperative learning model as the main activities in this learning model include analysis, synthesis, and evaluation.

Round Table cooperative learning model helps students to solve complex conceptual problems as they can discuss the problems with other students. In addition to external factors, students' critical thinking skills are also affected by internal factors, such as learning motivation. Motivation will encourage someone to do certain activities, including learning activities, in order to achieve the expected goals. Hence, the higher the student's motivation, the higher the student's critical thinking skill will be.

The problems discussed in this study are formulated into the following questions:

a. Are there any differences on the level of critical thinking skills between students who were taught by using Round Table and those who were taught by using lecture method in class $\mathrm{X}$ of SMA Negeri 1 Cilimus?

b. Are there any differences on the level of critical thinking skills between students who have high, moderate, and low learning motivation in class X of SMA Negeri 1 Cilimus?

c. Are there any effects of the interaction between Round Table learning model and students' learning motivation on students' critical thinking skills in class X of SMA Negeri 1 Cilimus? 


\section{Method}

This study applied a quasi-experimental method. According to Arikunto [2], "quasiexperimental method is a research method that is intended to determine whether or not there is an effect of 'something' imposed on the subject investigated." Meanwhile, the research design employed in this study was a $2 \times 3$ factorial design. In this present study, the independent variable A was the learning models consisting of Round Table cooperative learning model applied in experimental class and Lecture Method applied in control class. Then, the independent variable $\mathrm{B}$ was learning motivation consisting of low, moderate, and high learning motivation. Based on the results of the preliminary study, class X IPS 3 and X IPS 4 of SMA Negeri 1 Cilimus which have homogeneous characteristics and same number of students (35 students) were selected as the subjects of this study. Here, class X IPS 3 is decided to be the control class and class X IPS 4 is the experimental class. The data in this study were collected through tests and questionnaires.

\section{Result and Discussion}

\subsection{Description of pre-test}

Table 1. Results of pre-test data analysis of the experimental and control class

\begin{tabular}{|c|c|c|c|c|c|}
\hline \multicolumn{6}{|c|}{ Descriptive Statistics } \\
\hline Class & $\mathrm{N}$ & Minimum & Maximum & Mean & Std. Deviation \\
\hline Control & 35 & 35 & 70 & 49,33 & 9,14 \\
\hline Experiment & 35 & 35 & 75 & 51,4 & 10,24 \\
\hline
\end{tabular}

Based on Table 1, it can be discovered that the scores got by the control class which was taught by applying lecture method and the experimental class which was taught by applying Round Table cooperative learning model were not significantly different. The average score of the control class was 49.33 with the highest score of 70 , the lowest score of 35 , and a standard deviation of 9.14. Meanwhile, the average score of the experimental class was 51.4 with the highest score of 75, the lowest score of 35, and a standard deviation of 10.24.

\subsection{Description of post-test}

Table 2. Results of post-test data analysis of the experimental and control class

\begin{tabular}{|c|c|c|c|c|c|}
\hline \multicolumn{6}{|c|}{ Descriptive Statistics } \\
\hline Class & $\mathrm{N}$ & Minimum & Maximum & Mean & Std. Deviation \\
\hline Control & 35 & 50 & 85 & 66,04 & 8,77 \\
\hline Experiment & 35 & 55 & 95 & 79,80 & 10,57 \\
\hline
\end{tabular}

Table 2 shows that the average score of the control class taught by applying lecture method was 66.04 with the highest score of 85 , the lowest score of 50, and a standard deviation of 8.77 . Meanwhile, the average score of the experimental class taught by applying Round Table cooperative learning model was 79.80 with the highest score of 95, the lowest score of 55, and a standard deviation of 10.57 . 


\subsection{Description of students' learning motivation}

Table 3. Results of Students' Learning Motivation Data Analysis of The Experimental And Control Class

\begin{tabular}{|c|c|c|c|c|}
\hline Learning Model & $\begin{array}{c}\text { Students' Learning } \\
\text { Motivation }\end{array}$ & Mean & $\begin{array}{c}\text { Std. } \\
\text { Deviation }\end{array}$ & Total \\
\hline \multirow[t]{4}{*}{ Lecture } & Low & 45,33 & 1,211 & 6 \\
\hline & Moderate & 58,96 & 5,295 & 24 \\
\hline & High & 75,20 & 4,817 & 5 \\
\hline & Total & 58,97 & 9,651 & 35 \\
\hline \multirow[t]{4}{*}{ Round Table } & Low & 53,50 & 2,646 & 4 \\
\hline & Moderate & 77,70 & 4,915 & 21 \\
\hline & High & 84,00 & 2,494 & 10 \\
\hline & Total & 68,83 & 11,102 & 35 \\
\hline \multirow[t]{4}{*}{ Total } & Low & 48,60 & 4,575 & 10 \\
\hline & Moderate & 61,56 & 5,790 & 45 \\
\hline & High & 81,07 & 5,391 & 15 \\
\hline & Total & 63,89 & 11,471 & 70 \\
\hline
\end{tabular}

From Table 3, it can be seen that in the control class which was taught by applying lecture method, there were 6 students with low learning motivation, 24 students with moderate learning motivation, and 5 students with high learning motivation. Meanwhile, in the experimental class which was taught by applying Round Table cooperative learning model, there were 4 students with low learning motivation, 21 students with moderate learning motivation, and 10 students with high learning motivation.

\subsection{Hypothesis testing}

Table 4. Results of hypothesis testing

Dependent Variable: Critical thinking skills

\begin{tabular}{lrrrrrr}
\hline Source & $\begin{array}{c}\text { Type III Sum of } \\
\text { Squares }\end{array}$ & Df & Mean Square & \multicolumn{1}{c}{ F } & \multicolumn{1}{c}{ Sig. } & $\begin{array}{c}\text { Partial Eta } \\
\text { Squared }\end{array}$ \\
\hline Corrected Model & $6407,024^{\mathrm{a}}$ & 5 & 1281,405 & 25,949 &, 000 &, 670 \\
Intercept & 235787,776 & 1 & 235787,776 & 4774,729 &, 000 &, 987 \\
Model & 1238,608 & 1 & 1238,608 & 25,082 &, 000 &, 282 \\
Motivation & 2697,669 & 2 & 1348,835 & 27,314 &, 000 &, 460 \\
model * motivation & 111,492 & 2 & 55,746 & 1,129 &, 330 &, 034 \\
Error & 3160,476 & 64 & 49,382 & & & \\
Total & 387725,000 & 70 & & & & \\
Corrected Total & 9567,500 & 69 & & & & \\
\hline
\end{tabular}

a. R Squared $=, 670$ (Adjusted R Squared $=, 644$ )

Based on the results of the hypothesis testing presented in Table 4, it can be concluded that:

a. Round Table cooperative learning model can improve students' critical thinking skills as it can be seen from the $F$ value of 25.082 and the significance value of $0.000<0.05$. Due to its significance value which is $<0.05$, it can be concluded that the independent variables have an effect on the dependent variable. Hence, the first hypothesis is accepted. It implies that there is a significant difference on the level of critical thinking skills between students who 
were taught by using Round Table cooperative learning model and those who were taught by using lecture method.

b. Learning motivation has an impact on students' critical thinking skills as it can be seen from the $F$ value of 27.314 and the significance value of $0.000<0.05$. Hence, the second hypothesis is accepted. It means that there is a difference on the level of critical thinking skills between students who have high, moderate, and low learning motivation.

c. For the third hypothesis, it was found that the significance value was 0.330 and the $F$ value was 1.129 . The significance value which is $>0.05$ indicates that the hypothesis is rejected. It proves that there is no effect of the interaction between Round Table cooperative learning model and students' learning motivation on students' critical thinking skills.

The results of the hypothesis testing indicate that students' critical thinking skills can be improved by using Round Table cooperative learning model. The increased level of students' critical thinking skills is due to the main activities in this learning model which encourage students to analyze, synthesize, and evaluate a problem faced. Besides, Round Table cooperative learning model requires students to express their own ideas so that each student has to give an opinion and play an active role in solving a problem. The active role of the students in the learning process will certainly affect their critical thinking skills and will also have an impact on their learning outcomes, including their cognitive, affective, and psychomotor.

As stated by Haladyna and Shaughnessy in Stahl [3], teacher's teaching strategies as well as learning environment play a crucial role in developing students' thinking skills. An effective teaching strategy will definitely stimulate students to be able to analyze, interpret, respond, and evaluate a problem [4]. Learning activities in Round Table cooperative learning model are also able to train students to listen to instructions carefully and then carry out these instructions quickly and responsively. Students who are smart can then help weak students directly or indirectly. Through Round Table cooperative learning model, students are accustomed to express their ideas. Thus, Round Table cooperative learning model has a function to build cooperative skills, social skills, communicative skills, innovative learning skills, and critical thinking skills.

According to Arends [5] and Noor [6], the knowledge the students receive depends on what is taught by the teacher. Therefore, the orientation of learning should be shifted from learning to remember to learning to think. In the end, the goals of the learning process in the classroom are to make students to have basic skills for logical and critical thinking, curiosity, inquiry, and problem solving as well as social skills for them to live in their surrounding environment [7]. Critical thinking skill is one of the four skills that students need to have in this 21 st century education, in addition to communicative skill, collaborative skill, and creativity [8]. Besides, this higher-order thinking skill is required in facing various challenges that get more complex in the 21st century. In this case, Paul in Fisher [9] defines critical thinking skill as a mode of thinking where the thinker improves the quality of his thinking by handling the structures inherent in his thinking and applying certain intellectual standards to it.

In addition, the implementation of Round Table cooperative learning model in the experimental class made students more interested in learning, especially in finding solutions to the problems discussed. This activity is able to promote students' critical thinking skills because each student must work together in providing solutions to the problems being discussed. 


\section{Conclusion}

Based on the results of the analysis, the following conclusions are drawn:

1. There is a difference on the level of critical thinking skills between students who were taught by using Round Table and those who were taught by using lecture method. The level of critical thinking skills of students who were taught by using Round Table cooperative learning model is higher than those who were taught by using lecture method.

2. There is a difference on the level of critical thinking skills between students who have high, moderate, and low learning motivation. Students who have high learning motivation have higher critical thinking skills than students who have moderate or low learning motivation.

3. There is no effect of the interaction between Round Table cooperative learning model and students' learning motivation on students' critical thinking skills. It means that Round Table cooperative learning model and learning motivation do not simultaneously affect students' critical thinking skills.

\section{References}

[1] Susilo J 2009 Sukses dengan Gaya Belajar (Yogyakarta: Pinus)

[2] Arikunto S 2006 Prosedur Penelitian Suatu Pendekatan Praktik (Jakarta: Rineka Cipta)

[3] Stahl J 2008 A vision of powerful teaching and learning in the social studies: Building social understanding and civic efficacy J. for Soc. Stud. 13

[4] Shukla D and Dungsungneon A P 2016 Student's perceived level and teachers' teaching strategies of higher order thinking skills: A study on higher educational institution in Thailand J. of Ed. and Prac. 7 pp 211-219

[5] Arends R I 2013 Learning to Teach (Jakarta: Salemba Humanika)

[6] Noor A M 2009 Pedagogical issues in integrating thinking skills in the classroom Int. J. for Ed. Stud. 2 pp 55-68

[7] Kemendikbud 2014 Permendikbud No. 58 tahun 2014 tentang Panduan Pengembangan Materi Pembelajaran Kurikulum 2013 (Jakarta: Kementerian Pendidikan dan Kebudayaan)

[8] Zevin J 2007 Social Studies for the Twenty-First Century (New Jersey: Lawrence Erlbaum Associates, Inc)

[9] Fisher A 2009 Critical Thinking An Introduction (Jakarta: Erlangga) 